melanin deposits (Figure 2-5). Thus a diagnosis of metastatic deposit of malignant melanoma with a probable site of primary in the anorectum.

\section{Discussion}

Malignant melanoma is an uncommon tumor but is the most common tumor that metastasizes to the gastrointestinal tract. ${ }^{4-}$

6 Endoscopy is a useful diagnostic tool, which may detect various lesions like submucosal nodule, polypoidal mass, gastric ulcer. ${ }^{4}$ Melanotic lesions are common and sometimes the lesion may be amelanotic. Small bowel is the commonest site of GI tract for metastasis. Stomach and duodenum are rare site of metastasis. ${ }^{5,6}$ The presentation of patients also varies from patient to patient. Dyspepsia, GI bleeding, abdominal pain, epigastric mass are some of the common presentations. ${ }^{7}$ Anorectal melanoma is a very rare tumor with poor prognosis. ${ }^{8}$ It is often mistaken for benign conditions such as hemorrhoids or rectal polyp which delays the diagnosis.

H.S. DAS ${ }^{1}$

C. PANDA $^{2}$ $\mathrm{SPADHI}^{2}$ S. P. SINGH ${ }^{1}$

Correspondence: Dr. H.S. Das Department of Gastroenterology $y^{1}$ and Pathology ${ }^{2}$ S.C.B. Medical College, Cuttack 753007, Orissa, India.

Email: hbsrho@yahoo.co.in

\section{References}

1. Frost DB, Mercado PD, Tyrell JS. Small bowel cancer: a 30-year review. Ann Surg Oncol. 1994;1:290-5.

2. Reintgen DS, Thompson W, Garbutt J, Seigler HF. Radiologic, endoscopic, and surgical considerations of melanoma metastatic to the gastrointestinal tract. Surgery. 1984;95:635-9.

3. Backman H. Metastases of malignant melanoma in the gastrointestinal tract. Geriatrics. 1969;24:112-20.

4. Oda, Kondo H, Yamao T, Saito D, Ono H, Gotoda T, et al. Metastatic tumors to the stomach: analysis of 54 patients diagnosed at endoscopy and 347 autopsy cases. Endoscopy. 2001;33:507-10.

5. Liang KV, Sanderson SO, Nowakowski GS, Arora AS. Metastatic malignant melanoma of the gastrointestinal tract. Mayo Clin Proc. 2006;81:511-6.

6. Maladi V, Palanivelu C, Mathew S, Rajan PS, Jani K, Senthikumaran $\mathrm{S}$, et al. Malignant melanoma metastatic to the stomach and duodenum. Indian J Gastroenterol. 2005;24:133.

7. Wysocki WM, Komorowski AL, Darasz Z. Gastrointestinal metastases from malignant melanoma. report of a case. Surg Today. 2004;34:542-6.
8. Biyikoglu I, Ozturk ZA, Koklu S, Babali A, Akay H, Filik L, et al. Primary anorectal malignant melanoma: two case reports and review of the literature. Clin Colorectal Cancer. 2007;6:532-5.

\title{
Inflammatory myofibroblastic tumor of gall bladder
}

\section{Introduction}

Inflammatory myofibroblastic tumor (IMT) is a very rare low grade malignant tumor with a potential to arise from any organ. Histologically, there is fibrous tissue proliferation without atypia in a back ground of chronic inflammatory cells. Although many hypothesis exist; neoplastic, infectious, reparative, or immunologic, the true etiology of IMT is unclear. ${ }^{1,2}$ IMT of gall bladder is very rare. Only four case reports of IMT of gall bladder are available in literature. ${ }^{3-6} \mathrm{We}$ report a case of IMT of gall bladder in a patient with suspected cancer of gall bladder, who underwent radical cholecystectomy for gall bladder mass lesion.

\section{Case Report}

A 35 year old premenopausal woman presented to the hospital with history of low grade fever (on and off) and dull aching, irregular pain in right hypochondrium (unrelated to food) with occasional radiation to the back and right shoulder since 3 years. On clinical examination, gall bladder was palpable, smooth, firm with rounded margins and moving with respiration. Her hemoglobin was $10.7 \mathrm{gm} / \mathrm{dl}$, serum bilirubin $0.6 \mathrm{mg} / \mathrm{dl}$, AST $32 \mathrm{IU} / \mathrm{L}$, ALT $28 \mathrm{IU} / \mathrm{L}$, ALP $199 \mathrm{IU} / \mathrm{L}$, albumin $4.6 \mathrm{gm} / \mathrm{dl}$. Ultrasonography of the abdomen showed a mass lesion in fundus with a single large stone in gall bladder. Contrast enhanced computed tomography of abdomen and pelvis (Figure 1) revealed a mass lesion in the fundus of gall bladder. The plane with segment $\mathrm{V}$ of liver was ill defined with doubtful invasion of second part of duodenum. There were no significant lymph nodes along the hepatoduodenal ligament, peripancreatic, retroduodenal or celiac axis. She was a resident of Ganga river belt in northern India, which is a high risk region for carcinoma of gall bladder. ${ }^{7}$ With the above history, clinical findings and imaging, a clinical diagnosis of carcinoma gall bladder was made. 
A radical cholecystectomy was performed with en-bloc resection of segment IVB and V of liver and periportal, retropancreatic and retroduodenal lymphadenectomy. Intraoperatively, there was a mass in the fundus of gall bladder with involvement of segment V of liver. Postoperative recovery was uneventful. On gross examination, the cut section showed a grayish white tumor from the fundus of gall bladder, which on histopathological examination showed spindle cell proliferation without atypia in a back ground of plasma cells and lymphocytes. The spindle cells expressed smooth muscle antigen (SMA) on immunohistochemical staining suggestive of cells of myofibroblastic origin. The tumor was reaching up to the capsule of liver without invasion (Figure 2A-D). She was discharged from hospital on post-operative day 5. She is on regular follow up and disease free since last 2 years.

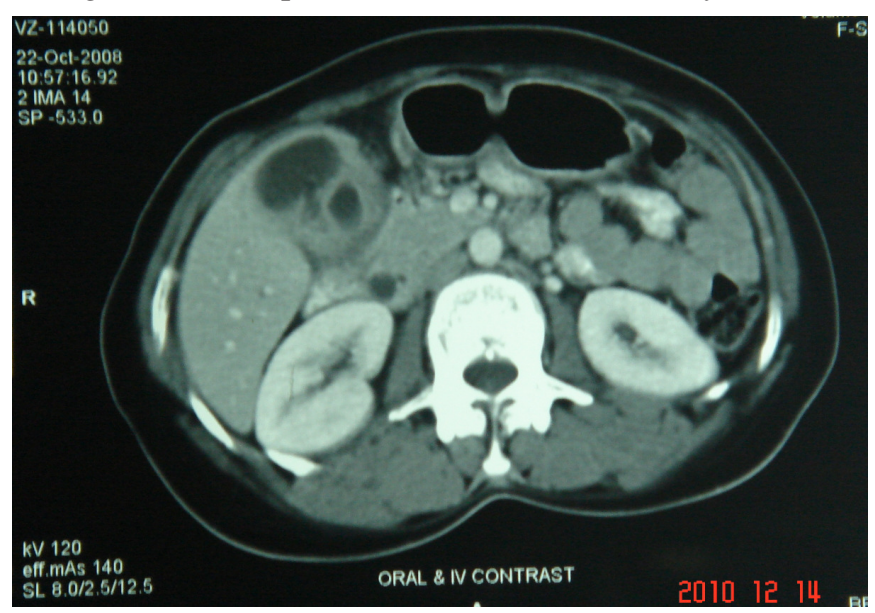

Figure 1: CT scan showing mass in the gall bladder.

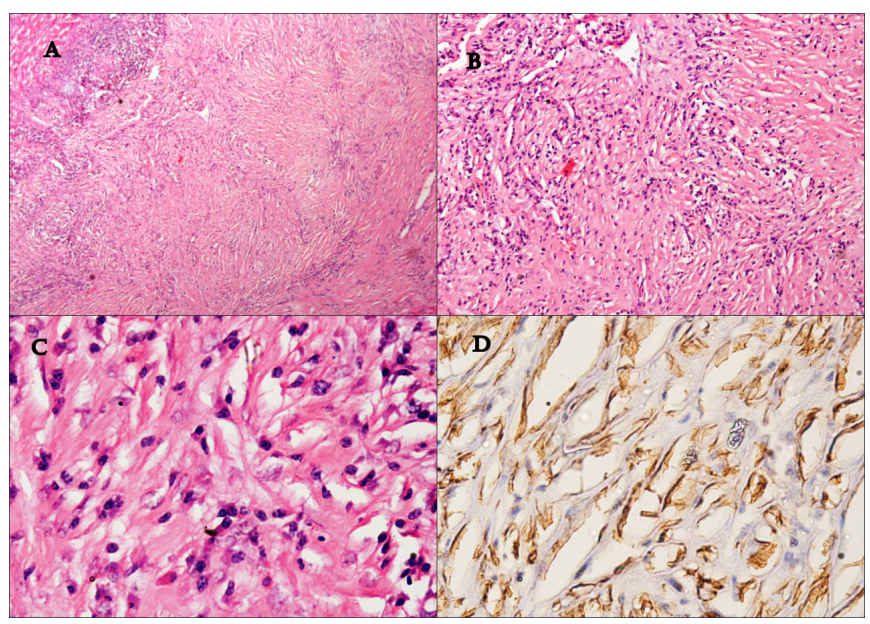

Figure 2: Photograph showing A. Proliferating myofibroblast with adjacent liver tissue (4X): B. and C. Fibroblast with plasma cell and lymphoid cell infiltration (10X and 40X): D. SMA positivity of myofibroblastic cells (40X)

\section{Discussion}

IMT is a rare slow growing tumor with a potential to arise from many organs. ${ }^{1}$ It has been variously named by different authors as inflammatory granuloma, inflammatory histiocytoma, plasmocytoma, plasma cell granuloma, pseudolymphoma and fibroxanthoma. ${ }^{2}$ IMT was first described by Brunn in 1939. ${ }^{3}$ and because of its resemblance to malignancy, it was named as "Inflammatory pseudotumor" by Umiker et al in 1954. ${ }^{4}$ Earlier IMT was considered as non-neoplastic, but is currently considered as a tumor with low-grade malignant potential because of local recurrence, infiltrative growth pattern, vascular invasion and malignant transformation. ${ }^{5}$

IMTs are rare tumors of undefined origin. Exact etiology is not known, although infection with inflammation has been proposed to be a causative factor. The new designation of "inflammatory myofibroblastic tumor" has replaced the earlier nomenclature of "inflammatory pseudotumor," because the cell of origin was established as a myofibroblast by immunohistochemical markers and electron microscopic studies. ${ }^{5}$ Although, most commonly occur in the lung 6 , IMT can occur in any organ. They have been reported in liver, orbit, brain, spinal cord, lymph nodes, breast, thyroid gland, spleen, oesophagus, stomach, pancreas, gallbladder, retroperitoneum, ovaries, urinary bladder, kidney and larynx. Although IMT of liver and biliary tract is uncommon, liver is the most common site of hepatobiliary IMT. ${ }^{3}$

Nonsurgical interventions have also been described in literature for IMT of lung and liver in patients with preoperative histological diagnosis of IMT. These patients can be observed with close and regular follow-up until the condition resolves by itself or needed any further intervention. ${ }^{7}$ There are case reports of complete resolution of the disease with steroids and NSAIDs. ${ }^{8}$ There are no case reports of IMT of gall bladder

being treated by conservative means.

Malignant transformations and recurrences of IMT have been reported to occur between four to seven years after surgery. ${ }^{1,9}$ Therefore, long-term follow up is necessary even for patients who have been successfully treated by surgical resection. The current case is disease free at 2 years after surgery. Few case reports are described in literature regarding metastatic potential of IMTs. ${ }^{10}$ Whether the recurrences were true metastasis and how the authors have differentiated from second primary lesions or multifocal disease has not been described in these reports. Lifelong follow up is necessary even in patients with radical surgery, as the exact biological behavior of IMT is unknown.

D. MUDULY ${ }^{1}$

S.V.S. DEO ${ }^{1}$

N.K. SHUKLA ${ }^{1}$ 


\section{N.M.L. MANJUNATH ${ }^{1}$ P. DURGAPAL ${ }^{2}$ A. KALLIANPUR ${ }^{1}$}

Corresondence: Dr. D. K. Muduly Department of Surgical Oncology ${ }^{\prime}, \mathrm{Dr} B R A-I R C H$ and Department of Pathology, ${ }^{2}$ All India Institute of Medical Sciences, New Delhi, India 110029

Email:dillipmuduly@gmail.com

\section{References}

1. Hagenstad CT, Kilpatrick SE, Pettenati MJ, Savage PD. Inflammatory myofibroblastic tumor with bone marrow involvement. A case report and review of the literature. Arch Pathol Lab Med. 2003;127:865-7.

2. Shek TW, Ng IO, Chan KW. Inflammatory pseudotumor of the liver. Report of four cases and review of literature. Am J Surg Pathol. 1993;17:231-8.

3. Narla LD, Newman B, Spottswood SS, Narla S, Kolli R. Inflammatory pseudotumor. RadioGraphics. 2003;23:719-29.

4. Umiker WO, Iverson L. Postinflammatory tumors of the lung; report of four cases simulating xanthoma, fibroma, or plasma cell tumor. J Thorac Surg. 1954;28:55-63.

5. Coffin CM, Humphrey PA, Dehner LP. Extrapulmonary inflammatory myofibroblastic tumor: a clinical and pathological survey. Semin Diagn Pathol. 1998;15:85-101.

6. Zennaro H, Laurent F, Vergier B, Rauturier JF, Airaud JY, Jougon J, et al. Inflammatory myofibroblastic tumor of the lung (inflammatory pseudotumor): uncommon cause of solitary pulmonary nodule. Eur. Radiol. 1999;9:1205-7.

7. Koea JB, Broadhurst GW, Rodgers MS, McCall JL. Inflammatory pseudotumor of the liver: demographics, diagnosis, and the case for nonoperative management. $J$ Am Coll Surg. 2003;196:226-35.

8. Vassiliadis T, Vougiouklis N, Patsiaoura K, Mpoumponaris A, Nikolaidis N, Giouleme O, et al. Inflammatory pseudotumor of the liver successfully treated with nonsteroidal antiinflammatory drugs: a challenge diagnosis for one not so rare entity. Eur J Gastroenterol Hepatol. 2007;19:1016-20.

9. Pecorella I, Ciardi A, Memeo L, Trombetta G, de Quarto A, de Simone P, et al. Inflammatory pseudotumour of the liverevidence for malignant transformation. Pathol Res Pract. 1999;195:115-20.

10. Kuo PH, Spooner S, Deol P, Monchamp T. Metastatic inflammatory myofibroblastic tumor imaged by PET/CT. Clin Nucl Med. 2006;31:106-8.

\section{Carpet villous adenoma of the rectum in an incarcerated rectal prolapse}

\section{Introduction}

Villous adenomatous polyps of the colon represent a real potential for cancer development ${ }^{1}$. They also may be involved in abnormal secretory activity associated with diarrhea and electrolyte imbalance, rectal bleeding or obstruction ${ }^{2,3}$. Association between giant villous adenomas (carpet-like lesion) and rectal prolapse is uncommon ${ }^{4,5}$. We present a case of an 87 year old man presented to the emergency department because of an incarcerated rectal prolapse totally carpeted by a giant villous rectal adenoma.

\section{Case presentation}

An 87 year old man arrived to the emergency department because of incarcerated rectal prolapse of 6 hours duration. The patient had a history of obstructive airway disease, treated with salmeterol and fluticasone $(50+250 \mathrm{mcg}$, inhalation twice daily) and ipratropium $40 \mathrm{mcg}$ (inhalation, three times daily). $\mathrm{He}$ had a rectal prolapse diagnosed 5 years ago by a general practitioner, although, he always refused further colonoscopic evaluation or surgical treatment since the rectal prolapse was reducted spontaneously. Six months prior to presentation, the rectal prolapse needed a manual replacement after defecation. On admission, he did not refer abdominal pain, bleeding or diarrhea. He only mentioned chronic constipation and rarely urgency of defecation. Physical examination did not reveal abdominal pain or signs of intestinal obstruction. Rectal inspection revealed a sizable prolapse entirely carpeted by a large polypoid lesion (Figure 1). Mucosal congestion was also observed while ischemic alterations were limited. Manual reduction was unsuccessfully attempted. Abnormal laboratory findings included mild hypokalhemia $(3,2 \mathrm{mg} / \mathrm{dl})$ and hyponatremia $(130 \mathrm{mg} / \mathrm{dl})$.

A minimal mobilization and reduction was obtained under general anesthesia, however, a considerable part of the rectum and the associated neoplastic lesion was still protruding through the anus. We initially considered the aspect and the size of the neoplastic lesion regarding possible cancer degeneration, however, we excluded an operation that could combine oncologic benefits and simultaneously, repair of the incarcerated rectal prolapsed. We finally performed a perineal recto-sigmoidectomy (Altemeier's procedure). The postoperative course was uneventful. He was discharged 7 days later. The pathology report described a large villous adenoma occupying the entire circumference of the resected segment 